\title{
Policy Formulation Concerning Accelerate Development of Electric Motor Vehicles
}

\author{
Dyah Trihandini*
}

\author{
Universitas Kusuma Husada Surakarta \\ ${ }^{*}$ Corresponding author. Email: dyahtrihandini20@gmail.com
}

\begin{abstract}
The number of countries that have developed in terms of technology encourages the acceleration of innovation in the field of transportation. The development of innovation and technology in the vehicle sector creates an environmentally friendly electric-fueled vehicle. Electric vehicles can save the Earth's natural resources, making it more environmentally friendly and efficient. This article aims to find out the formulation of policies regarding the acceleration of the development of electric motorized vehicles.
\end{abstract}

Keywords: Policy, Vehicle, Electric Motor

\section{INTRODUCTION}

In 2018, transportation accounted for $45 \%$ of final energy consumption. About $94 \%$ of this energy consumption comes from burning petroleum fuel [1]. Mobility in Indonesia is dominated by passenger with $90 \%$ and accident in transport. In road transportation, private passenger vehicles (motorcycles and cars) dominate eet. Development on motorcycles and cars, there is an opportunity to reduce GHG emissions through the adoption of electric vehicles in these countries mode [2].

Many countries have experienced high levels of EV penetration and provided others with examples of important policy instruments in driving adoption, particularly through demand-side policy instruments. These instruments can be categorized into one-time fiscal incentives (eg tax exemptions, carbon charges on vehicle prices); recurring fiscal incentives (eg the price of carbon as a fuel tax, dynamics of electricity rates for charging EVs); regulatory incentives (eg mandatory fuel economy, exhaust standards); and non-financial incentives (eg charging infrastructure development, special lane access, toll exclusions, free parking, and access to low emission zones) [3].

Rapid technological developments support the creation of innovative and environmentally friendly vehicles with the use of electric power so that this article aims to find out the formulation of policies regarding the acceleration of the development of electric motorized vehicles.

\section{DISCUSSION}

\subsection{The Development of Electric Car Technology}

Having a battery as the main energy source is the basis of an electric car. However, currently what is more developed is the use of batteries and fuel oil together to drive a car. This concept is better known as a hybrid. Broadly speaking, we knew two main type of electric cars, namely Battery Electric Vehicle (BEV) and Plug in Hybrid Electric Vehicle (PHEV), which will be explained in detail in terms of types/types one by one [4].

\section{1) Battery Electric Vehicle (BEV)}

The energy stored will relying in the battery pack, BEV type electric car can cover a distance of 100 to 250 $\mathrm{km}$ on a single full charge. For a higher class, the distance can be further up to 300 to $500 \mathrm{~km}$. This mileage is also affected by style of the driver's age, road conditions, climate, and battery type. Because it only relies on the power stored in the battery, the BEV type electric car does not emit emissions such as carbon 
dioxide (CO2) and other pollutant emissions, such as heavy metals, namely lead $(\mathrm{Pb})$. There are various kinds of batteries that are applied to electric cars. Figure 1 shows a diagram/plot of some common battery technologies, which are used to compare the energy densities of various (size and weight) energy storage devices (smaller size and lighter weight) [5].

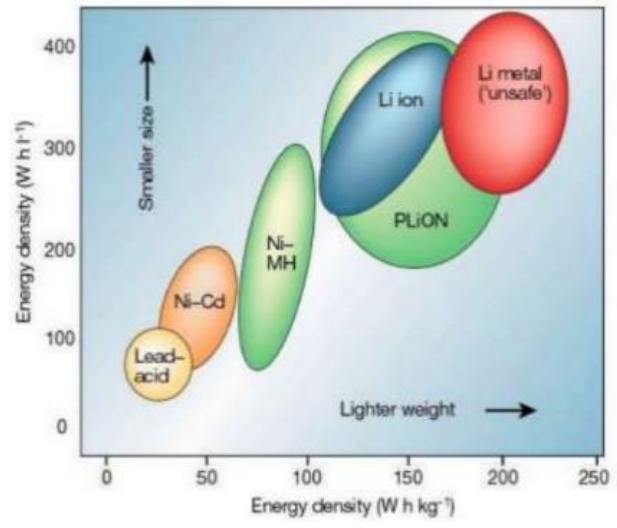

Figure 1. Energy densities of various

A battery is basically storage medium consisting of two electrodes on an electrolyte. These electrolytes provide medium for exchange of ions that generate electricity. Each of the batteries has unique advantages and disadvantages, although recent innovations in $\mathrm{Li}$ ion batteries have propelled them to become market leaders for use in most handheld and portable electronics and electric vehicles. This is mainly due to their specific energy $(\mathrm{Wh} / \mathrm{kg})$, life-cycle, and high efficiency. They have disadvantages which include high costs and complex safety with monitoring systems [6].

\section{2) First type: Series Hybrid}
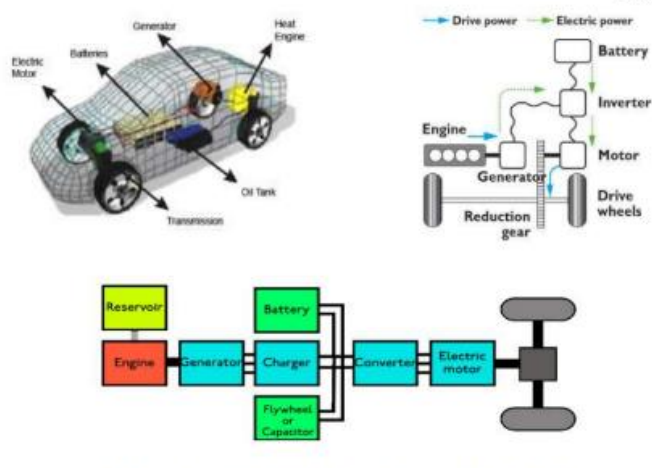

- Gambar 3. Struktur kendaraan PHEV dalam sistem hibrid seri [11].

Figure 2. The structure of a PHEV vehicle

The combustion engine series hybrid system does not turn the wheels directly but an electric is providing power to the wheels. When electricity is needed in large quantities, the motor will draw electricity from the generator and the battery. Series hybrid configuration have been around for a long time, for example: dieselelectric locomotive, hydraulic earthmoving machine, diesel-electric power group. The structure of a PHEV vehicle in a series hybrid system. An example of this type of car is the Renault Kangoo [7].

\section{3) Sensor Technology}

The discussion of sensor technology is only focused on several environmental sensors around the vehicle (Radar, Lidar, Ultrasonic and Camera) which are used as a tool in detecting objects or objects that are around the car at a certain distance for the application of automatic vehicles (autonomous vehicles) as a continuation of the program. KBL Radio Detection and Ranging (Radar) is an object and distance detection technology utilizing the reflection of radio waves. The wavelength emitted by the radar varies greatly. ${ }^{6}$. In the general radar system, the frequency of $24 \mathrm{GHz}$ or 77 $\mathrm{GHz}$ is used. Each wavelength or frequency has its own advantages. The $77 \mathrm{GHz}$ frequency has the advantage of high distance accuracy and more precise speed measurement. While the advantage of using the $24 \mathrm{GHz}$ frequency is the need for a smaller antenna so as to minimize the occurrence of interference to both external and internal systems. The fundamental difference is in the application of radar technology which is used for short, medium or long range detection. For short distances, the use of radar can be used as a parking assist system, lane/aisle detection, blind spot detection, automatic distance control, braking guidance and so on. For medium or long distances, radar can be used to identify dangerous situations and prevent collisions [5].

\section{4) Lidar}

Lidar (Light Detection and Ranging) can detect surrounding objects by utilizing reflected light. Lidar technology can be utilized to measure the properties of scattered light and find distance or other information from distant targets. The light source used is light radiation produced by a laser. The laser will send a (TX) beam to the object that later reflected and received by a receiver (RX) which is sensitive to laser light. The laser light that is sent is in the visible light or invisible light dimension in the form of an infrared beam and receiver [4]

\section{5) Ultrasonik}

The working principle of ultrasonic devices is almost the same as Radar and Lidar technology. There are differences in the frequency used, where ultrasonic technology uses ultrasonic sound beams and receivers with a frequency range above the human audible sound range or $>20 \mathrm{kHz}$. The ultrasonic device will emit a signal that is used to measure the distance to the object in front of it [5].

\section{6) Camera}

The camera technology embedded in electric cars is a 360-degree camera type to capture a complete picture of the conditions around the car. The camera can be 
called the driver's additional eye to see the situation around the car. The results obtained by the camera can be directly displayed on the driver's monitor, or with the help of a digital image processing system it can automatically detect surrounding objects and provide input to the control system which is then executed by the actuator unit. For the development of higher technology, the application of this camera sensor can assist in realizing an automated vehicle system (Autonomous Vehicle) [6].

Automated vehicle technology may be a continuation of the KBL program in the future, but safety must be a major concern. Below is given a few paragraphs as an additional explanation regarding this technology [2].

\subsection{Automated Vehicle Technology}

In automated vehicle technology, cars can drive with little or no human control. The car is integrated with hardware (hardware) and software (software) in which an intelligent system has been embedded and programmed. Automatic vehicles combine various sensors and analyze the sensor data which can then detect and distinguish objects in the vehicle's environment. The results of the data analysis show the car can distinguish objects such as humans/pedestrians or other objects in the vicinity to avoid unwanted accidents. The method of controlling the control of an automatic vehicle uses hardware and software integration that utilizes artificial intelligence system algorithms in the form of machine and deep learning, so the system can learn and study various objects behavior in various conditions. Given that a lot of software is difficult to use and few can learn, there are several software that have been considered capable of meeting the needs of automated car systems [1].

All of these systems are built using one or a combination of the Java, C, C++, LISP, and other programming languages. Another system has been widely used is ADAS (Advanced Driver Assistant System) 2.

\section{a. Indonesian Government Support for Electric Cars}

The government is very serious in encouraging the development of the electric car technology industry. One of the ways is by providing incentives to the industry. Presidential Decree No. 55/2019 concerning the Acceleration of the Battery-Based KBL Program for Road Transportation. The incentives referred to include import duty incentives on the import of batterybased KBLs called completely knock down (CKD) or incompletely knock down (IKD) or main components for a certain amount and period of time. Other incentives can also be in the form of incentives for Sales Tax on Luxury Goods (PPnBM). The exemption or reduction of central and local taxes; import duty on the import of machinery, goods, and materials in the context of investment; suspension of import duty for export; and incentives for import duties borne by the government on imports of raw materials and auxiliary materials for the production process [2].

Furthermore, there are also incentives for the manufacture of general electric vehicle charging unit (SPKLU) equipment, export financing incentives, fiscal incentives for research and development, parking fees, reduction in the cost of charging electricity at SPKLU, support for SPKLU development financing, competency certification for KBL-based human resources. batteries, and product certification and technical standards for battery-based KBL industry companies. Non-fiscal incentives can be given include exemptions from restrictions on the use of certain roads, delegation production rights to technology related to electricity $\mathrm{KBL}$, and development of operational security in the industrial sector. Finally, there are additional fiscal and non-fiscal incentives for the national branded KBL industry. The government is committed to developing a transportation energy system that leads to an electric-based vehicle (KBL) policy. Underlying the government's commitment to shifting conventional vehicles to $\mathrm{KBL}$ is the new technology for transportation energy to anticipate the projected growing demand for fuel oil. The main impact of the mass transition of road transportation to electric cars is the increase in the need for electrical energy on a large scale [8].

As an acceleration of the KBL program, support from all parties is needed in order to reduce the inhibiting factors that are considered by consumers' preferences in choosing KBL, namely price, maintenance, and durability of vehicles as well as infrastructure readiness. to KBL went well, supported by the readiness of the supporting infrastructure. In addition, the DPR also plays a role in ensuring that the government's performance in providing incentives for industry and community using KBL is right on target [14]. As a special follow-up to Presidential Regulation 55/2019, Governor Regulation (Pergub) No. 3 of 2020 concerning the tax incentive of Transfer of Names for Motorized Vehicles (BBN-KB) on Battery-Based Electric Motorized Vehicles is expected to spur the population of stun vehicles in the capital city 8 . With this regulation, now all pure electric motorcycles and cars in the DKI Jakarta area (an example of regional application), will not be subject to a $12.5 \% \mathrm{BBN}$ tax. Yes, as stated in Chapter II Article paragraph 2, all battery-based electric vehicles will not be subject to a biofuel tax. Other benefits specifically for those who have electric cars are also guaranteed to be free from the odd-even policy in Jakarta [9].

The Spirit of the Acceleration of the Battery-Based National Electric Motor Vehicle Program in 
Presidential Regulation Number 55 of 2019 concerning the Acceleration of the Battery Electric Vehicle Program for Road Transportation:

1) Acceleration of domestic battery-based KBL industry development

2) Providing incentives

3) Provision of electricity charging infrastructure and regulation of tariffs for Battery-Based KBL

4) Technical compliance provisions of BatteryBased KBL

5) Environment Protection [8]

Table 1. Prepress derivative policy 55/2019 [8]

\begin{tabular}{|c|c|}
\hline Policy & Policy Target \\
\hline $\begin{array}{l}\text { Peraturan Menteri } \\
\text { Dalam Negeri Nomor } \\
8 \text { Tahun } 2020\end{array}$ & $\begin{array}{l}\text { It is a legal umbrella } \\
\text { for the Regional } \\
\text { Government to provide } \\
\text { incentives for Motor } \\
\text { Vehicle Taxes and } \\
\text { Motor Vehicle Transfer } \\
\text { Fees, for people who } \\
\text { buy Electric Vehicles. }\end{array}$ \\
\hline $\begin{array}{l}\text { Peraturan Menteri } \\
\text { Perindustrian Nomor } \\
27 \text { Tahun } 2020\end{array}$ & \begin{tabular}{l}
\multicolumn{1}{c}{ Regulate the } \\
Roadmap and TKDN \\
calculation KBLBB
\end{tabular} \\
\hline $\begin{array}{l}\text { Tanda sah KBLBB, } \\
\text { Keputusan Korps Lalu } \\
\text { Lintas Polri Nomor } 5 \\
\text { Tahun } 2020\end{array}$ & $\begin{array}{l}\text { The process of } \\
\text { procuring TNKB } \\
\text { specifically for KBL- } \\
\text { BB has been } \\
\text { implemented and has } \\
\text { been distributed } \\
\text { throughout Indonesia }\end{array}$ \\
\hline $\begin{array}{l}\text { Kementerian } \\
\text { Keuangan }\end{array}$ & $\begin{array}{l}\text { Regulate procedures } \\
\text { for importing CBU in } \\
\text { the context of } \\
\text { investment }\end{array}$ \\
\hline $\begin{array}{l}\text { Peraturan Menteri } \\
\text { Perdagangan }\end{array}$ & $\begin{array}{l}\text { Regulate the } \\
\text { procedures and } \\
\text { specifications for the } \\
\text { import of lithium raw } \\
\text { materials }\end{array}$ \\
\hline
\end{tabular}

Mapping the need for electric bus components by the Ministry of SOEs

1) The local industry is strong, there are already 9 bodybuilding companies

2) Still imported, has the potential to be developed domestically, needs R \& D

3) Able to be produced domestically (PT INDAD), need $R \& D$ to improve product

4) Import due to LFP battery type, Need R\&D when use NMC. Battery [10]

Conditions that support the acceleration of electricfueled vehicles

1) The existence of the COVID-19 pandemic prompted a revision of the timeline for the implementation of the SPKLU development (revision of projected needs)

2) The issuance of the Minister of Energy and Mineral Resources No. August 13, 2020 has implications for:

a) Change of Business Model Scheme

b) Revised SPKLU Financial Feasibility Analysis Calculation

c) Revised SPKLU Technical Feasibility Analysis Calculation

d) The need for the SPBKLU development road map no later than 6 months from the signing of the Ministerial Regulation 10.

\section{CONCLUSION}

The use of the first electric car was introduced in 1828 and the first produced in 1884 . Where BEV is an electric car that only relies on energy stored in battery packs. While PHEV is a combination of a car that has two energy sources, namely electrical energy stored in batteries and energy sources from burning fuel oil. The Indonesian government strongly supports the development and marketing of electric cars. The government is committed to developing a transportation energy system that leads to an electricbased vehicle (KBL) policy. One way to get people interested in using electric-based vehicles (KBL) such as electric cars is by providing incentives such as reducing vehicle taxes and being free from odd-even programs on highways such as in the national capital.

However, in addition, the use of technologies such as radar, lidar, ultrasonic, and cameras (various sensors) to find objects around the car that can be integrated with software programmed and embedded in intelligent systems, will be able to replace the human position as a controller and make the vehicle automatic (autonomous vehicle). This technology is also expected 
to be a continuation of the KBL program and as a solution to reduce the carbon footprint in the future

\section{REFERENCES}

[1] MDPI, A Comprehensive Study of Key Electric Vehicle (EV) Components, Technologies, Challenges, Impacts, and Future Direction of Development, 2017.

[2] C. A. Julius, The Role of Electric Vehicles in Decarbonizing Indonesia's Road Transport Sector. Jakarta,Institute For Essential Services Reform (IESR), 2020.

[3] IRENA, Electric Vehicles: Technology Brief, International Renewable Energy Agency, Abu Dhabi, 2017.

[4] E. A. Grunditz, and T. Thiringer, Performance Analysis Of Current Bevs Based On A Comprehensive Review Of Specifications. IEEE

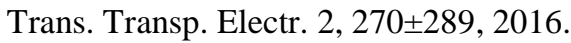

[5] Y. Miao, P. Hynan, A. Von Jouanne, A.Yokochi, Current Li-Ion Battery Technologies in Electric
Vehicles and Opportunities for Advancements. Energies, 12, 2019, 1074

[6] S. Martin, I. Fusanori, and K. Hideo, Current Situation of Electric Vehicles in ASEAN. States, Carmakers, and International Production Networks. ERIA Research Project Report FY2021 No.03, Jakarta: ERIA, 2021, pp.1-32.

[7] W. Sandra, H. Dale, N. Mike, L. Nic, Analyzing Policies to Grow the Electric Vehicle Market in European Cities. International Council On Clean Transportation, 2020.

[8] Peraturan Presiden Republik Indonesia Nomor 55 Tahun 2019 Tentang Percepatan Program Kendaraan Bermotor Listrik Berbasis Baterai (Battery Electric Vehiclq Untuk Transportasi Jalan

[9] Peraturan Pemerintah Republik Indonesia Nomor 30 Tahun 2021 Tentang Penyelenggaraan Bidang Lalu Lintas Dan Angkutan Jalan

[10] Peraturan Gubernur Bali Nomor 48 Tahun 2019 Tentang Penggunaan Kendaraan Bermotor Listrik Berbasis Baterai 